\title{
“Call Center” sebagai Alat Komunikasi Pemasaran di Abad ke-21
}

\author{
Ratih Tresnati \\ Call center is a part of contact center who responsible to serve customers. Call center relates \\ corporate and targeted market. As communication media whose tasks are focused to serve the \\ customers, call center receives and processes consumer expectations \\ and hopes. The result can be processed as an opportunity for the corporate to expand its market \\ and develop their products. Call center is believed could raise customer satisfactions by \\ reduced service costs for each customer in long term action plan.
}

Kata kunci: call center, contact center, media komunikasi, komunikasi pemasaran

\section{Pendahuluan}

Kemajuan teknologi telah menyediakan fasilitas berkomunikasi yang semakin canggih dan beragam. Dalam rangka memanfaatkan kemajuan telekomunikasi dan teknologi informasi (telematika), belum lama ini sebuah maskapai penerbangan nasional meluncurkan nomor telepon elok 0-807-1-807XYZ sebagai call center yang menjadi pusat informasi sekaligus pusat pelayanan.

Meski bukan suatu hal yang sama sekali baru, peluncuran call center yang dicanangkan sebagai sebuah hasil inovasi baru itu dilakukan secara gencar dan mendapat liputan yang cukup meriah dari berbagai media. Langkah ini kemudian ternyata juga diikuti oleh beberapa perusahaan baik swasta nasional maupun asing. Call center dijadikan banyak perusahaan sebagai alat komunikasi pemasaran mereka. Benarkah langkah itu tergolong inovasi yang memberikan terobosan kepada pengguna produk/jasa mereka?

\section{Komunikasi Pemasaran}

Promosi merupakan salah satu faktor penentu keberhasilan suatu program pemasaran. Betapapun berkualitasnya suatu produk, bila konsumen belum pernah mendengarnya dan tidak yakin bahwa produk itu akan berguna bagi mereka, maka mereka tidak akan pernah membelinya. Promosi adalah suatu bentuk komunikasi pemasaran, yang merupakan aktivitas pemasaran untuk menyebarkan informasi, membujuk, dan mengingatkan pasar sasaran atas produk perusahaan agar bersedia menerima, membeli, dan loyal pada produk yang ditawarkan perusahaan.

Pentingnya promosi digambarkan lewat perumpamaan bahwa pemasaran tanpa promosi dapat diibaratkan seorang pria berkaca mata hitam yang dari tempat gelap pada malam kelam mengedipkan matanya pada seorang gadis cantik di kejauhan. Tak seorang pun yang tahu apa yang dilakukan pria tersebut, selain dirinya sendiri 
(Fandy Tjiptono:1997). Seperti juga yang dikemukakan oleh Kotler (2003), Kotler \& Amstrong (2001), Kerin \& Peterson (1993), bahwa "Marketing Communication is the process by which infomation about an organization and its offerings is disseminated to selected markets. "Secara garis besar, proses komunikasi pemasaran dapat tampak pada gambar 1:

Ada tiga unsur pokok dalam struktur proses komunikasi pemasaran sebagaimana yang tergambar dalam Gambar 1, yaitu: (1) Pelaku Komunikasi.Terdiri atas pengirim (sender) yang menyampaikan pesan dan penerima pesan. Dalam konteks ini, komunkatornya adalah produsen, sedangkan komunikan (receiver)nya adalah khalayak, seperti pasar pribadi, pasar organisasi, dan masyarakat umum; (2) Material ko-munikasi, yaitu: (a) Gagasan, yaitu materi pokok yang hendak disampaikan pengirim; (b) Pesan, yaitu himpunan berbagai simbul (oral, verbal, atau nonverbal) dari suatu gagasan. Pesan hanya dikomunikasikan melalui suatu media; (c) Media, yaitu pembawa pesan komunikasi. Pilihan media komunikasi pemasaran bisa bersifat personal maupun nonpersonal; (d) Tanggapan, yaitu reaksi pemahaman atas pesan yang diterima oleh penerima; (e) Umpan balik dari sebagian atau keseluruhan tanggapan yang dikirim kembali oleh penerima; (f) Gangguan, yaitu segala sesuatu yang dapat menghambat kelancaran proses komunikasi; (3) Proses Komunikasi. Proses penyampaian pesan dan pengiriman kembali respon akan memerlukan dua kegiatan, yaitu encoding (adalah proses merancang atau mengubah gagasan secara simbolik menjadi sebuah pesan untuk disampaikan kepada penerima) dan decoding (adalah proses menguraikan atau mengartikan simbol sehingga pesan yang diterima dapat dipahami).

\subsection{Tujuan Komunikasi Pemasaran}

Komunikasi pemasaran meliputi tiga tujuan utama, yaitu untuk menyebarkan informasi (komunikasi informatif); mempengaruhiatau menarik konsumen untuk melakukan pembelian (komunikasi persuasif), dan mengingatkan khalayak untuk melakukan pembelian ulang (komunikasi mengingatkan kembali). (Kotler,2003; Kotler \& Amstrong, 2001).

Tanggapan konsumen sebagai komunikan terhadap stimuli meliputi: (a) Efek kognitif, yaitu membentuk kesadaran informasi tertentu. Di tahap ini, konsumen akan menyadari dan bertambah pengetahuannya; (b) Efek afeksi, yakni memberikan pengaruh untuk melakukan sesuatu yang diharapkan adalah realisasi pembelian. Di tahap ini konsumen akan menyukai, lebih menyukai dan yakin; Efek konatif atau perilaku, yaitu membentuk pola khalayak. Ditahap ini konsumen akan cenderung membeli; (c) Perilaku konsumen selanjutnya, yang diharapkan penjual adalah pembelian ulang.

\subsection{Alat Promosi (Promotion Tools)}

Menurut Kotler (2003; Kotler \& Amstrong, 2001), alat-alat promosi terdiri dari:

(1) Advertising, adalah semua bentuk penyajian

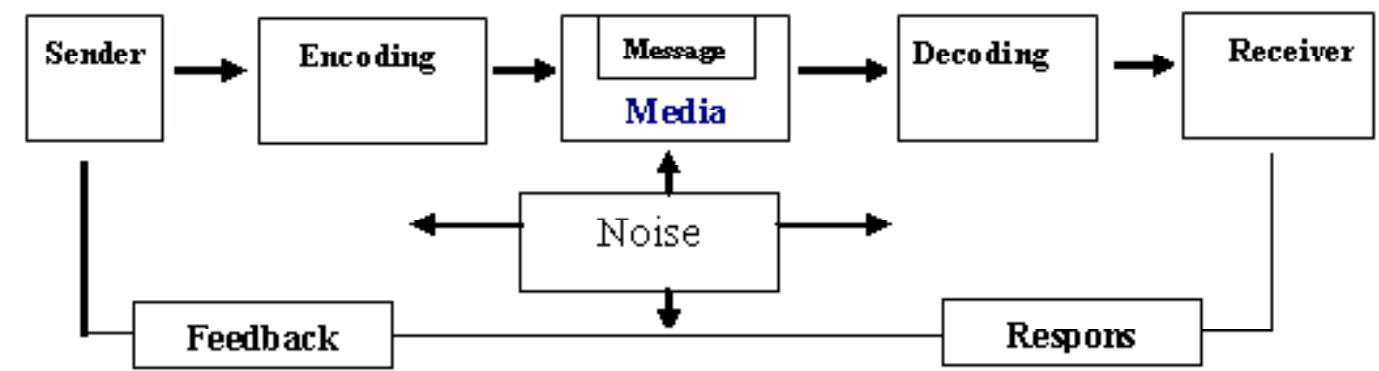

Sumber : Kotler (2003), Kotler and Amstrong (2001), Keren \& Peterson (1993), Gambar 1 : Model Komunikasi Pemasaran 
dan promosi nonpersonal atas ide, barang atau jasa yang dilakukan oleh perusahaan sponsor tertentu. Advertising menggunakan media, seperti TV, radio, kemasan, katalog, brosur, leaflet, majalah, billboard, spanduk, sibol, logo, balon udara, mobil box, Film dan sebagainya.

(2) Sales Promotion, adalah berbagai insentif jangka pendek untuk mendorong keinginan mencoba atau membeli suatu produk atau jasa.

(3) Public Relation \& Publicity, adalah berbagai program untuk mempromosikan dan atau melindungi citra perusahaan atau masingmasing produknya.

(4) Personal Selling adalah interkasi langsung antara salesman perusahaan dengan satu atau lebih calon pembeli guna melakukan presentasi, menjawab pertanyaan, dan menerima pesan.

(5) Direct Marketing adalah penggunaan surat, telepon, facsimile, e-mail, dan alat-alat penghubungan nonpersonal lainnya untuk berkomunikasi secara langsung dengan atau mendapatkan tanggapan langsung dari pelanggan dan calon pelanggan.

\subsection{Pemasaran Langsung (Direct Marketing)}

Pemasaran langsung adalah sistem pemasaran interaktif yang menggunakan satu, atau lebih, media iklan untuk menghasilkan tanggapan dan/atau transaksi yang dapat diukur pada suatu lokasi (Kotler,2003:345; Kotler \& Amstrong, 2001:250).

Definisi ini menekankan pada tanggapan yang dapat diukur, khususnya pesanan pelanggan. Karena itu, pemasaran langsung kadang-kadang disebut direct-order-marketing (pemasaran pesanan langsung). Kini, banyak pemasar menganggap pemasaran langsung memainkan peranan yang lebih luas, yaitu membangun hubungan jangka panjang dengan pelanggan ( $r e-$ lationship marketing), di mana relationship marketing merupakan salah satu cara mempertahankan pelanggan. Dengan perkataan lain, pemasaran langsung dalam arti luas sama dengan relationship marketing.
Menurut Kotler (2003:228), pemasaran hubungan (relationship marketing) adalah "Proses menciptakan, mempertahankan, dan memperbaiki hubungan yang kuat yang berdasarkan nilai, dengan pelanggan dan pemegang saham lainnya."

Salah satu unsur fundamental dari relationship dengan pelanggan adalah fokus pada ketahanan pelanggan. Unsur lain adalah penghargaan terhadap nilai seorang pelanggan. Tujuan dari hubungan yang sejati dengan pelanggan adalah kepuasan jangka panjang yang melampaui transaksi individual (Barnes, 2001:23). Contoh-contoh pemasaran langsung dalam arti luas yang dilakukan oleh Perusahaan, yaitu: perusahaan mengirimkan kartu ulang tahun kepada pelanggannya, memberikan parcel pada event Lebaran atau Natal/Tahun Baru, perusahaan penerbangan memberikan Frequent Fliers Miles (bonus untuk pemakaian jasa penerbangan berdasarkan jumlah mil yang ditempuh), menawarkan pelanggan untuk menjadi anggota kelompok pelanggan dengan memberikan member card.

Adapun manfaat pemasaran langsung bagi konsumen akhir, antara lain, memberikan kesenangan,memberikan kenyamanan, memberikan kemudahan, dapat berhemat waktu, dapat melakukan belanja komparatif dengan membaca katalog dan layanan belanja online. Sedangkan manfaat pemasaran langsung bagi konsumen bisnis, baik produsen, pedagang besar maupun pengecer, antara lain, penjual dapat membeli sebuah daftar alamat yang memuat nama dari hampir semua kelompok konsumen akhir (kelompok orang kidal, kelompok orang-orang kegemukan, kelompok jutawan, dan sebagainya). Dengan pemasaran langsung, dapat diatur agar penjual dapat menjangkau calon konsumen yang tepat sasaran, material pemasaran langsung memiliki tingkat bacaan yang lebih tinggi, karena dikirim pada calon pembeli yang lebih berminat.

\subsection{Saluran/Media atau Alat Utama Pemasaran Langsung}

Saluran/media atau alat utama pemasaran langsung yaitu: (1) face to face selling, (2) direct mail, (3) catalog marketing, (4) telemarketing, (5) 
others media for direct response marketing, (6) kios marketing, (7) electronic marketing (Kotler:2003).

(1) Face-to face selling (Penjualan Tatap Muka) - Personal Selling. Bentuk pertama dan tertua dari direct marketing adalah face-to face selling atau personal selling (= di mana penjual bertemu langsung dengan calon pelanggan).

(2) Direct Mail Marketing (Pemasaran melalui Media Surat Langsung). Direct mail adalah pengiriman penawaran, pemberitahuan, pengingat, atau hal-hal lain kepada seseorang di alamat tertentu. Dengan menggunakan daftar alamat yang sangat selektif, pemasaran langsung mengirimkan jutaan paket pos setiap tahun - surat, selebaran, brosur. Media direct mail marketing, yaitu: facsimile, e-mail, voice mail.

(3) Catalog Marketing (Pemasaran melalui Media Katalog). Catalog Marketing terjadi jika perusahaan mengirimkan satu, atau lebih, katalog produk pada penerima terpilih yang kemungkinan besar akan memesan produk tersebut.

(4) Telemarketing (Pemasaran melalui Telepon). Telemarketing telah menjadi peralatan utama direct marketing. Beberapa sistem Telemarketing diotomatisasi penuh, seperti automatic-dialing and recorded message players (ADRMPS) dapat memutar nomor, pesan iklan yang diaktifkan dengan suara, dan dapat menerima pesanan dari pelanggan yang tertarik melalui mesin penjawab telepon.

(5) Media Lain dengan Pemasaran melalui Tanggapan Langsung. Media pemasaran langsung lainnya yang digunakan untuk mendapatkan tanggapan langsung dari pelanggan, yaitu: surat kabar, majalah, televisi.

(6) Kiosk Marketing (Pemasaran Langsung melalui Kios). Kiosk marketing, pada dasarnya, merupakan "mesin penerima pesanan pelanggan" yang dinamakan Kiosk yang ditempatkan di toko, bandara, dan tempat-tempat lain. Contoh: Forsheim Shoe Company menempatkan sebuah mesin di beberapa tokonya, yang memungkinkan pelanggan menentukan jenis sepatu, warna, dan ukuran yang diinginkannya. Gambar sepatu Forsheim muncul di layar sesuai dengan kriterianya. Jika sepatu tertentu tidak tersedia di toko tersebut, pelanggan dapat menggunakan telepon yang ada di mesin tersebut dan memasukkan nomor kartu kreditnya, serta di mana sepatu tersebut harus dikirim.

(7) Electronic Marketing (Pemasaran melalaui Elektronik). Saluran/media direct marketing terbaru adalah melalui eletronik, di mana calon pelanggan dapat menjangkau penjual melalui komputer atau modem - dikenal dengan marketing online (pemasaran melalui komputer dan modem). Online marketing disebut sebagai alat komunikasi abad sekarang. Ia pada dasarnya ,merupakan saluran yang dapat dijangkau seseorang melalui komputer dan modem. Modem menghubungkan komputer dengan jalur telepon sehingga komputer menjangkau beragam layanan informasi online (Kotler:2003).

Jenis online marketing, yaitu: a) commercial online marketing; b) internet, yaitu jaringan global sekitar 45.000 jaringan komputer yang memungkinkan komunikasi global yang instan dan terdesentralisasi.

Manfaat online marketing, yaitu: memberikan kemudahan, memberikan informasi, menawarkan rongrongan yang lebih sedikit, artinya pelanggan tidak perlu menghadapi atau melayani bujukan dan faktor-faktor emosional, memberikan penyesuaian yang cepat terhadap kondisi pasar, artinya penjual/ pemasar dapat dengan cepat menambahkan produk pada penawaran mereka serta mengubah harga dan deskripsi penawarannya, biaya yang lebih rendah, artinya penjual/pemasar dapat mencegah biaya pengelolaan toko dan biaya sewa, biaya asuransi, dan biaya prasarana lainnya yang menyertai produk yang ditawarkan kepada calon pelanggan, pemupukan hubungan.

Pemasar dapat menjalankan online marketing dalam empat cara, yaitu: (1) dengan membuat etalase elektronik-Home page; (2) berpartisipasi dalam forum, (3) news-group; (4) buletin boards; 
(5) memasang iklan online; (6) menggunakan $e$ mail; (7) menggunakan call center (Kotler:2003).

\section{Call Center}

Perusahaan yang peduli akan kepuasan pelanggan akan terus menerus memfasilitasi kemudahan akses pelanggan ke perusahaan. Dengan adanya saluran akses, pelanggan akan makin yakin bahwa berhubungan dengan perusahaan ternyata hanya sebatas jangkauan tangan, sebatas meraih telepon tetap, telepon genggam, atau sebatas membuka website, internet dan e-mail (Agung, 2006:37).

Sejalan dengan perkembangan keberadaan communication channel, maka perkembangan saluran akses untuk pelanggan makin menggembirakan. Demikian pula dengan keinginan pelanggan untuk makin menggunakan saluran akses ini pun, terlihat semakin meningkat.

Awalnya, perusahaan membuka saluran komunikasi lewat alat komunikasi konvensional, seperti, telepon. Oleh sebab itu, saluran ini sering disebut sebagai call center yang tadinya digunakan untuk menerima telepon masuk saja (in bound) menjadi berkembang. Dengan berkembangnya software database pelanggan, sekarang call center dapat digunakan secara aktif oleh perusahaan untuk menghubungi pelanggan (outbound). Dalam kemampuannya untuk menghubungkan dan dihubungi inilah tercipta suatu konsep etalase bagi call center. Konsep ini menekankan bahwa saluran ini sebagai delivery channel bagi perusahaan, sama halnya dengan delivery channel lainnya yang konvensional. Jika semula call center digunakan oleh perusahaan jasa, maka saat ini call center digunakan juga oleh perusahaan produk fisik, seperti mobil, barangbarang elektronik.

Call Center pada intinya merupakan pusat layanan pelanggan. Pada awalnya kontak pelanggan $100 \%$ menggunakan telepon, kemudian dengan berkembangnya teknologi, munculah intelegent network yang salah satu aplikasinya menggunakan nomor bebas pulsa. Melihat perkembangan teknologi komunikasi dan minat masyarakat untuk terus mengikuti dan menggunakan perangkat IT untuk memudahkan dan mempercepat jalur komunikasi, maka minat masyarakat terhadap call center juga meningkat. (Jahari, 2006:23).

Kesadaran perusahaan akan pentingnya call center sudah sangat meningkat seiring dengan tingkat persaingan yang semakin sengit. Call Center sudah dianggap sebagai keharusan yang tersedia sebagai jembatan yang menghubungkan antara perusahaan/produk dengan pelanggannya tanpa batas. Paradigma perusahaan pun mulai bergeser, di mana sebelumnya call center hanya dianggap sebagai cost center, kini sebagian sudah menganggapnya sebagai profit center. Jika sebelumnya call center hanya dimanfaatkan untuk menampung informasi dan keluhan, sekarang call center dimanfaatkan juga untuk kegiatan selling.

Dewasa ini hadir pula teknologi voice network dengan memanfaatkan internet sebagai jalur suara. Perkembangan penyediaan multiple channel of communication dari perusahaan kepada pelanggan dengan menyediakan perangkat website, internet, e-mail, SMS, dan lain-lainnya, akhirnya melahirkan suatu konsep contact center. Jadi, contact center, pada intinya, merupakan pusat layanan pelanggan yang memiliki multi channel seperti telepon, e-mail, chatting, atau facsimiles yang terintegrasi. Call center kini hanya menjadi bagian dalam contact center.

\subsection{Tujuan Call Center}

Tujuan call center pertama-tama adalah untuk memberikan suatu media buat para konsumen atau pasar sasaran berbicara dengan perusahaan. Dengan adanya media tersebut, perusahaan akan mampu menampung apa keinginan dan harapan konsumen terhadap produk-produk perusahaan. Dengan mengetahui harapan dan keinginan para konsumen, maka perusahaan merupakan peluang untuk melakukan inovasi, peningkatan mutu produk (Marcelina J. Gunawan - Consumer Advisory Service Manager PT. Unilever Indonesia Tbk., dalam Jahari, 2006:23).

Sebaik-baiknya call center, tentunya tidak akan berarti jika para konsumen tidak menyadari kehadiran nomor call center-nya. Untuk itu, 
beberapa pemilik call center berusaha mencari unique number bagi call center nya. Bahkan jika dimungkinkan, nomor tersebut memiliki link (kaitan) dengan mereknya. Hal ini ditunjukkan dengan perilaku beberapa perusahaan yang berburu "nomor cantik" yang diinginkannya dengan cara mentender ke perusahaan- perusahaan penyedia. Contoh: Bank Niaga, untuk mendapatkan nomor cantik bagi call center nya "14041" dengan cara melakukan tender kepada beberapa perusahaan. Perusahaan yang dimenangkan saat itu adalah yang berani menjanjikan nomor yang diminta Bank Niaga.

\subsection{Bentuk-bentuk Penanganan Call Center}

Penanganan call center di berbagai perusahaan dapat terbagi ke dalam dua bentuk, yaitu in-house dan outsource. Baik in-house maupun outsource memiliki keunggulan dan kelemahan masing-masing. Baik in-house maupun outsource memiliki karakteristik yang berbeda.

In-house call center pada dasarnya call center yang dibuat dengan menggunakan sumber daya yang dimiliki seseorang. Perusahaan yang menyelenggarakan call center secara in-house, biasanya, memiliki sejumlah alasan. Selain ingin me-ngendalikan sendiri sumber daya dan aplikasi untuk mendukung kebutuhan pelanggan, perusahaan umumnya telah memiliki infrastruktur besar yang bisa dimanfaatkan. Pemilik call center in-house juga akan memberlakukan call center sebagai investasi modal daripada sebagai biaya operasional jangka panjang.

Sedangkan perusahaan yang melakukan outsourcing, mereka menginginkan agar perusahaan lebih fokus ke usaha inti sambil memanfaatkan mitra yang lebih kompeten untuk dukungan pelanggan. Apalagi mereka tidak memiliki Sumber Daya Manusia (SDM) yang cukup untuk melayani kontak pelanggan dalam volume besar. Perusahaan yang menggunakan call center outsource semacam ini lebih menanggap biaya call center sebagai operating cost daripada capital cost. Namun, mungkin juga pemilik call center melakukan outsourcing karena menginginkan adanya solusi sementara sampai kapabilitas inhouse bisa dibangun oleh perusahaan tersebut.

Namun, call center yang dikelola sendiri atau tidak, yang jelas kehadiran call center tidak boleh lepas dari fungsi utamanya, yaitu "sebagai jembatan antara pelanggan dan perusahaan". Menjadi agen call center bukanlah pekerjaan yang mudah. Bisa jadi, psikis, mereka terganggu akibat menerima komplain setiap hari. Karena itulah, program-program motivasi tak surut diberikan kepada mereka. Bila tidak, yang terjadi adalah turn-over karyawan yang tinggi. Masa 2-3 tahun biasanya dianggap sebagai batas setiap agen untuk bekerja di call center. Setelah itu, entah habis masa kontrak atau mereka mengundurkan diri untuk bekerja di tempat lain.

\subsection{Tipe Call Center Dilihat dari Jenis Bisnis}

Dilihat dari jenis bisnisnya, call center dapat dibedakan dalam empat kategori (Indrajit, 2006:30) yaitu:

(1) Tipe Cost Center. Hal ini terjadi karena perusahaan menjual produk dengan janji bahwa after sales service nya bagus dan akan ditanggung oleh perusahaan, seperti jasa pengantaran, garansi, jasa perbaikan selama garansi. Bagi perusahaan, after sales service tersebut merupakan cost, sedangkan bagi pelanggan, after sales service tersebut merupakan service karena dia tidak membayar apa-apa untuk mendapatkannya.

(2) Tipe yang sifatnya profit (profit center). Call center bersifat profit, karena setiap kali telepon ada pembayaran. Sebenarnya setiap kali telepon yang dilakukan adalah penjualan service (jasa).

(3) Tipe call center sebagai investment. Mengingat persaingan sedemikian ketat, maka perusahaan ingin memberikan nilai ke konsumen, yang berbeda dari perusahaan pesaingnya. Oleh karena itu, dibangunlah sebuah call center yang besar, di mana pelanggan bisa berinteraksi hanya dengan bayaran pulsa biasa.

(4) Tipe call center sebagai service center. Artinya, call center perusahaan dengan 
tujuannya memberikan pelayanan kepada para pelanggannya agar supaya mereka puas bahkan menjadi loyal dengan apa yang diberikan perusahaan.

\subsection{Teknologi Call Center}

Call center bukan cuma sekadar cost center. Call Center sendiri pada dasarnya merupakan cara alternatif yang murah untuk melakukan customer contact daripada harus bertatap muka dengan pelanggan. Merupakan tantangan ke depan bagi perusahaan-perusahaan untuk menjadikan call center sebagai profit center. Oleh sebab itu, berbagai usaha pun dilakukan untuk menekan biaya pada call center, sekaligus menjadikannya sebagai profit center. Salah satunya melalui teknologi. Teknologi adalah komitmen perusahaan terhadap call center. Teknologi dan besarnya jumlah investasi tergantung pada strategic intent, yang memosisikan call center, apakah hanya sebagai pendukung atau sebagai delivery channel dan image center.

Di luar negri, kini mulai banyak perusahaan yang mempergunakan teknologi VoIP (Voice Over Internet Protocol) untuk menekan biaya pulsa. Lagi pula, di sana teknologi VoIP sudah jauh lebih baik daripada di Indonesia.

Ada lagi teknologi voice recognizer, yakni mesin yang bisa menuntun Anda dan dan menjawab pertanyaan dari suara yang Anda keluarkan. Namun, ada kelemahannya, di mana teknologi tinggi semacam itu juga berisiko hilangnya kepuasan pelanggan karena tidak adanya personal touch.

Teknologi memang bisa dijadikan alternatif untuk menggantikan biaya SDM yang tinggi. Tak heran, banyak pemilik merek call center di Amerika Serikat dan Australia melakukan outsource call center nya ke negara-negara Asia Pasifik, seperti negara Filipina, Malaysia, dan India. Ketiga negara tersebut menjadi negara tujuan outsource call center karena kemampuan bahasa Inggris di negaranegara tersebut tergolong baik. Dengan melakukan outsourcing ke luar negri, maka call center di negara-negara maju dapat menekan biaya per call menjadi hanya US $\$ 5$.
Di Indonesia, fenomena outsource call center sudah banyak dilakukan (sekalipun kepada agen dalam negri) sudah banyak dilakukan, khususnya perusahaan besar. Contoh: Bank Niaga memilih untuk melakukan outsource dengan menggandeng Info Media sebagai partner, dan ia mendapatkan nomor cantik 1404.

Menurut Jahari (2006:25), ada banyak jenis teknologi yang digunakan pada call center, yaitu (1) CTI (Computer Telephone Integration). CTI adalah teknologi yang mengintegrasikan berbagai sambungan telepon dan komputer sehingga memungkinkan antara suara dan jaringan data bekerja sama dan saling memberikan informasi. Dengan adanya CTI, setiap telepon, facsimile, $e$ mail, atau SMS yang masuk, akan diidentifikasikan dan kemudian dioper ke departemen atau bagian yangberwenang secara cepat. CTI juga memungkinkan pengidentifikasian nomor pelanggan untuk kemudian ditransfer ke daerah terdekat dengan pelanggan; (2) IVR (Interactive Voice Response); (3) Voice Recognizer yakni mesin yang bisa menuntun Anda dan dan menjawab pertanyaan dari suara yang Anda keluarkan. Namun, ada kelemahannya, di mana teknologi tinggi semacam itu juga berisiko hilangnya kepuasan pelanggan karena tidak adanya personal touch; (4) Software in-bound \& outbound; (5) Sistem B24; (6) Telepon Digital; (7) Software dari Avaya; (8) PABX; (9) Headset; (10) Online System, Global Cyber SVC Center; (11) FAQ System; (12) SMS Notification; (13) GPS (Global Positioning System); (14) Internet Protocol Contacct Center (IPCC), agar call yang masuk bisa langsung didistribusikan pada agen mana yang siap, tidak perlu menunggu; (15) VoIP (Voice Over Internet Protocol) yang fungsinya untuk menekan biaya pulsa.

\subsection{Aspek-aspek Pokok dalam Pengelolaan Call Center}

Menurut Agung (2005:37), dalam pengelolaan call center agar efektif, ada tiga aspek utama yang harus diperhatikan, yaitu (1) System; (2) People; (3) Technology.

System. Keefektifan sistem yang diaplikasikan 
harus dibuat sederhana dan mencakup kebutuhan dan keinginan pelanggan. Sistem dan prosedur yang berbelit-belit akan melemahkan konsep call center yang menawarkan "kepraktisan dan kecepatan."

People, adalah agen-agen yang melayani dan berkomunikasi langsung dengan pelanggan. Kemampuan interpersonal dan intrapersonal skill agen sangat menentukan. Berkomunikasi tanpa bertatap muka memerlukan ketrampilan lebih tinggi dibandingkan dengan bertatap muka. Oleh karena itu, perusahaan dituntut menempatkan agen-agen yang terampil untuk melayani pelanggan.

People,terutama in-bound agent menjadi isu paling besar dalam pengelolaan call center. Selain menciptakan biaya yang tinggi, kinerja mereka juga menjadi penentu baik buruknya penilaian pelanggan terhadap service provider. Contoh: sebuah call center bank yang harus melayani 15.000 incoming call center per hari, mereka akan membutuhkan 150 agen. Jika para agen call center digaji pada upah minimum (satu juta rupiah per bulan), maka dalam setahun biaya untuk menggaji para agen sebesar 1,9-2 milyar rupiah. Biaya karyawan tersebut, belum termasuk biaya gedung, biaya percakapan, biaya perawatan, dan infrastruktur yang tidak terhitung murah. Itulah sebabnya, ratusan juta rupiah sampai milyaran rupiah bisa ke luar untuk melakukan investasi call center.

Pendapat yang sama juga dikemukakan oleh Jahari (2006:24) yang mengatakan bahwa "pada akhirnya, kemampuan soft skill (menyangkut kemampuan berkomunikasi, keramahan dan ketanggapan petugas) dan hard skill (menyangkut pengetahuan produk yang baik) agen akan menjadi penentu terakhir saat berhubungan dengan call center." Untuk meningkatkan kemampuan kedua aspek ini, mau tidak mau, perusahaan harus mengeluarkan biaya pelatihan yang terus menerus. Apalagi jika tingkat turn over dari para agen juga tinggi. Selain itu juga, quality monitoring perlu dilakukan untuk mengevaluasi kinerja agen pada kedua aspek tersebut. Contoh: Bill Customer Care menetapkan satu supervisi untuk memonitor delapan buah agennya. Setiap percakapan agen bisa didengar, bahkan direkam. Hasil rekaman ini yang djadikan alat untuk memicu kinerja agen. Pada sebuah call center, SDM merupakan suatu hal yang penting sekali. Jika agen tidak bagus, maka keseluruhan perusahaan juga tampak tidak bagus.

Teknologi, adalah komitmen perusahaan terhadap call center. Teknologi dan besarnya jumlah investasi tergantung pada strategic intent, yang memosisikan call center apakah hanya sebagai pendukung atau sebagai delivery channel dan image center.

Berbagai perusahaan (terutama perbankan dan perusahaan penerbangan) telah merasakan manfaat saluran komunikasi ini. Di samping membantu pelanggan untuk mendapatkan layanan lebih cepat, juga dapat membantu perusahaan meningkatkan kepuasan pelanggan.

Call center dapat membantu perusahaan meningkatkan kepuasan pelanggan, dengan alasan:

(1) Biaya kontak per pelanggan ke perusahaan lebih murah dibandingkan dengan menyediakan waktu khusus bagi pelanggan untuk datang ke tempat layanan. Demikian juga bagi perusahaan, makin banyak tempat layana disediakan biaya investasi dan biaya operasional menjadi semakin mahal. Dengan call center, biaya pelayanan per pelanggan dapat ditekan dalam jangka menengah dan jangka panjang.

(2) Karena akses pelanggan ke perusahaan lebih cepat dan lebih murah, maka pelanggan yang dilayani dengan tuntas akan jauh lebih puas, karena telah mendapatkan value yang diinginkan. Artinya, manfaat yang diperoleh lebih besar daripada biaya yang dikeluarkan.

(3) Pelanggan makin yakin akan profesionalisme perusahaan yang memiliki contact center atau minimal call center. Jadi, call center yang dikelola dengan baik, bukan saja berfungsi sebagai contact center, tetapi juga dapat meningkatkan image perusahaan.

\subsection{Nomor Cantik dan Pelayanan Cantik pada Call Center}

Bicara tentang call center, tidak dapat dilepaskan dari nomor yang digunakan. Biasanya, semakin "cantik" nomor yang dipakai, maka akan 
semakin mudah konsumen mengingatnya. Hal ini tentunya akan memperkuat awareness dan aksesabilitas call center tersebut (Simatupang, 2006:41). Contoh: Nomor call center Bank Mandiri 14000 .

Namun nomor cantik, tentunya, tidak banyak berarti jika tidak dibarengi dengan layanan yang cantik pula. Oleh karea itu, agar perusahaan dapat memberikan layanan yang cantik, selain memberikan nomor yang cantik, maka perusahaan harus me-nyediakan para pegawai/agen yang bekerja dalam shift pagi, siang, dan malam dengan pengaturan WIB, WITA, dan WIT.

\subsection{Hal-hal yang Harus Dipertimbangkan}

Menurut Indrajit (2005:30), mula-mula dilihat dulu bisnis apa yang akan perusahaan masuki, kemudian menentukan pposisi call center ada di mana, setelah itu tipe call center mana yang akan diadopsi (apakah tipe cost center, atau tipe profit center, atau service center atau investment call center). Langkah selanjutnya, perusahaan tersebut harus menetapkan kapan membutuhkan outsource call center? Perusahaan memutuskan untuk melakukan outsourcing, yaitu ketika (1) sumber daya (resources) tidak cukup (misalnya, SDM yang bersikap ramah). Bila SDM yang diharapkan memenuhi standar yang telah ditetapkan untuk menjadi agen call center milik perusahaan tidak cukup jumlahnya, maka sebaiknya dalam pengelolaannya dengan outsourcing; (2) Pengetahuan (knowledge), bagaimana cara mengomunikasikan produk/jasa perusahaan dengan cara yang mudah dimengerti pelanggan. Bila SDM yang dimiliki perusahaan dianggap tidak mampu melakukan komunikasi yang baik dengan pelanggan atau calon pelanggan, maka sebaiknya dalam pengelolaan call centernya menggunakan outsourcing.

\subsection{Kendala-kendala dalam Menjalankan Call Center}

Ada beberapa kendala dalam menjalankan call center, yaitu:

(1) Infrastruktur. Pengadaan infrastruktur bagi sebuah call center yang meliputi high tech yang harganya mahal, telah menjadi kendala bagi banyak perusahaan yang ingin mempunyai call center.

(2) Paradigma shift (mengubah pola pikir, baik dari produsen maupun dari pelanggan). Paradigma yang ada di mana pelanggan merasa memiliki hak penuh atas barang/jasa yang dibelinya. Dia tidak akan membeli barang yang tidak jelas perusahaannya atau bagaimana menghubunginya. Sebaliknya, di pihak perusahaan, persaingan sudah sedemikian ketat. Perusahaan harus jemput bola, person to person. Salah satu caranya, lewat call center. Paradigma yang baik adalah perusahaan akan semakin baik bisnisnya bila dia bermitra dengan pelanggannya. Bila perlu, pelanggan membantu membuat produk. Mereka adalah "staf ahli yang bagus". Jadi, pelanggan dilibatkan dalam pembuatan produk perusahaan melalui, komplain, harapan, dan ide-ide mereka.

(3) Keamanan bagi call center yang melakukan transaksi. Para pengusaha call center, dihadapkan pada semakin canggihnya kejahatan dalam bisnis call center.

\subsection{Perkembangan Call Center di Indonesia}

Di Indonesia, layanan call center awalnya dipelopori oleh industri perbankan. Salah satu yag mendasarinya adalah pertimbangan cost efficiency. Mengingat, biaya melayani seseorang nasabah di teller cabang ternyata lebih mahal daripada biaya pelayanan melalui call center. Selain itu juga, bahwa Kantor Cabang tidak dapat selalu stand by 24 jam nonstop, sedangkan keperluan nasabah kadang tidak mengenal waktu (David S. Simatupang, 2005:40).

Selain itu, juga mengingat bank adalah "bisnis kepercayaan", maka eksistensinya harus jelas. Dan, call center punya arti penting sebagai satu bukti bahwa nasabah bisa selalu berkomunikasi dengan perusahaan.

Indonesia mencatat pertumbuhan pasar call center yang sangat signifikan sejak 2001. Booming-nya mulai tahun 2004. Dari data riset yang ada, 
pertumbuhannya mencapai $19,1 \%$ sampai pada tahun 2008. Analisis Frost \& Sullivan memperkirakan pertumbuhannya hingga 2008 nanti akan mencapai 19,1\% dengan potensi pasarnya yang pada 2004 mencapai Rp 54 triliun. Ini berangkat dari pemikiran bagaimana supaya $\mathrm{cus}$ tomer itu loyal, supaya mereka menjadi long life customer

Tidak ada cara lain perusahaan harus berpartner dengan pelanggan. Salah satu caranya adalah melalui channel call center. Indonesia juga diprediksikan berpotensi akan menjadi pusat call center kawasan (regional) seperti Filipina yang banyak menyediakan call center dari negaranegara Amerika Serikat dan Negara-negara Eropa. Hal tersebut sangat memungkinkan terjadi di Indonesia, karena kecenderungan di berbagai industri sudah menjadikan call center sebagai fasilitas layanan yang harus tersedia. Apalagi, Indonesia memiliki jumlah penduduk yang sangat besar, mencapai 250 juta, yang menempati sekitar 17.000 pulau. Sementara, call center merupakan solusi low cost yang sangat efektif dan sangat ideal untuk pasar yang besar seperti Indonesia sebagai negara kepulauan ( Indrajit,2006:30).

Beberapa perusahaan yang memberikan Pelayanan Call Center, antara lain sebagai berikut:

PT Bank Permata Tbk. Tahun ini, Permata Tel sebuah call center milik PT.Bank

Permata Tbk. melejit ke posisi tertinggi dalam indeks call center service excellence. Kondisi ini dapat dicapai oleh Permata Tel karena beberapa hal, antara lain: (1) Perusahaan merasakan bahwa biaya melayani nasabah di teller cabang ternyata lebih mahal daripada biaya pelayanan melalui call center; (2) Perusahaan menyadari benar bahwa bank adalah bisnis kepercayaan, sehingga eksistensinya harus jelas; (3) Bahwa call center punya arti penting sebagai bukti bahwa nasabah bisa selalu berkomunikasi dengan perusahaan. Nasabah, bila pergi ke call center, pasti ingin ketemu manusia (Irma Meutia-GM Call Center \& Service Quality Bank Permata, dalam Simatupang, 2005:40)

Permata Tel mengelola call center sendiri, dengan alasan untuk menjaga standarisasi kualitas
SDM. Jika pengelolaan call center dengan outsourcing, mereka khawatir akan mendapatkan SDM yang tidak sesuai dengan harapan mereka. Saat ini Permata Tel memiliki 180-an SDM termasuk 1 head, 6 manager, 18 supervisor, dan sekitar 160 agen. Para agen yang dibagi dalam 4 5 shift per hari ini, sebelum berinteraksi dengan nasabah, telah menjalani berbagai training, antara lain: tentang product knowledge, pengetahuan sistem, communication skill yang baik. Dalam sehari, mereka rata-rata menerima 15.000 call.Meskipun demikian, tidak semua telepon yang datang langsung akan masuk ke agen, karena Permata Tel telah berhasil mengedukasi nasabah untuk menggunakan mesin saja, bila ingin menanyakan hal-hal redundan/berlebih-lebihan seperti saldo. Artinya, investasi Permata Tel sudah dapat dinikmati oleh para nasabah. Sedangkan para agen Permata Tel benar-benar dipersiapkan untuk menerima "komplain dari para nasabah". Pelayanan yang diberikan call center Permata Tel yang beroperasi sejak tahun 2003 ini mencakup: information delivery, customer care, complain handling, plus transaksi. Pelayanan ini dapat diperoleh oleh nasabah melalui sistem Interactive Voice Recognizer (IVR) atau melalui manusia. Namun, khusus tentang pelayanan "komplain" akan ditangani melalui manusia/SDM.

PT Garuda Indonesia. Nomor sebuah call center memang gampang dihafal dan memudahkan pelanggan untuk menelepon. Tak heran, meskipun konon harganya mahal, sejumlah call center berlomba-lomba untuk mendapatkannya. Ini pula yang membuat PT. Garuda Indonesia untuk mengganti nomor call center nya dari semula 0807 1427832 menjadi 08071807807 . Guna memperkenalkan nomor cantik tersebut, PT Garuda Indonesia menggelar sederetan kampanye. Dari mulai acara peluncuran, iklan di bandara, pencantuman nomor cantik tersebut di kartu nama karyawan, sehingga menjadi sponsor penyelenggaraan Miss Universe ( Pujobroto-Vice President Corporate Communication Garuda Indonesia dalam Simatupang, 2006:44).

Namun, keunggulan Garuda Call Center $(G C C)$ tidaklah sekadar punya nomor cantik saja, 
pelanggan juga dimanjakan dengan segudang layanan. Mereka, umpamanya, tidak perlu panik bila tiba-tiba ingin beli tiket di tengah malam. Mereka tinggal pencet nomor GCC, maka tiket yang diinginkan pun akan diperolehnya. Selain itu, transaksi bisa pula dilakukan lewat online payment . Di sini, pelanggan dapat memilih sendiri, apakah pembayarannya akan dilakukan melalui ATM, internet banking, phone banking, atau mobile banking, atau credit card. Layanan yang diberikan GCC ini tergolong lengkap. Hal ini mengingat PT Garuda Indonesa ingin mengembangkan call center-nya menjadi One Stop Service bagi semua kebutuhan pelanggannya, yang antara lain meliputi layanan jadwal penerbangan, reservasi/memesan tiket pesawat, Garuda Frequent Flyer, phone check-in, bahkan komplain. Semuanya dapat dilakukan di GCC tersebut. GCC di-outsource-kan ke PT Telkom yang mengelola teknologi dan SDM. Meskipun pengelolaan GCC dengan outsourcing, namun PT Garuda menetapkan standar layanan yang diharapkan, kualitas SDM, serta service level-nya. Para agen mereka bekali dengan latihan tentang product knowledge. GCC menempatkan supervisor untuk memonitor dan mengevaluasi kinerja para agen. GCC diawaki oleh sekitar 300 agen yang dibagi dalam 10 shift per hari. Masing-masing bekerja kurang lebih 8 jam sehari. Pada saat peak time GCC menempatkan 150 agen yang bertugas.

PT Astra Toyota Motor. Menjual produk, terutama yang berkaitan dengan after sales service seperti otomotif, perlu perhatian yang berkelanjutan. Apalagi bila pelanggannya belum tentu punya kepentingan untuk membeli, bisa saja ia datang ke dealer hanya sekedar mencari informasi awal, sehingga ada keengganan untuk datang. Hal itu bisa dihindari dengan hadirnya call center Toyota Astra Motor (TAM). Jadi, misi perusahaan ingin open larger window for customer (membuka jendela lebih lebar/seluas-luasnya bagi pelanggan) - Harsono - Customer Service Manager TAM.

Call center TAM yang dikenal dengan nama Toyota Hotline hadir sejak 1991 yang awalnya diarahkan untuk menangani after sales service, namun kemudian dikembangkan dengan nama Toyota Hotline pada tahun 1996 dengan nomor call center 08001821333 . Layanan yang ditawarkan kepada pelanggan terbagi kedalam tiga bagian, yaitu: (1) Informasi tentang produk; (2) Informasi tentang penjualan (yang mencakup harga, jaringan; (3) timing peluncuran produk baru. Toyota Hotline beroperasi dari pukul 08.00 hingga 16.45 WIB alias jam kantor dengan 5 orang agen (full time). Tetapi sebagai antisipasi, setiap harikecuali hari Sabtu dan Minggu - ditugasi dua orang petugas after office hingga pukul 19.00. Selanjutnya, dari pukul 19.00-07.00 pagi disediakan voice recording.

Garda Oto Asuransi. Customer Satisfaction Index (CSI) Garda Oto sudah mencapai angka 91\%, artinya sebagai sebuah perusahaan asuransi kendaraan bermotor, kehadirannya sudah diterima secara baik oleh konsumen. Banyak faktor yang memengaruhi hal tersebut, namun salah satu penyumbangnya adalah divisi call center. Di Garuda Oto, call center-nya bernama "Garda Akses 24 jam", dengan nomor call center 021-7191919. Sesuai kampanye Peace of Mind yang digelindingkan perusahaan Asuransi Astra, Garda Oto menterjemahkannya ke dalam startegi pelayanan yang disebut "Riang" - ringkas, andal, dan mengesankan. Dengan strategi ini, Garda Oto ingin mengubah persepsi asuransi kendaraan bermotor menjadi mudah dan nyaman (Anna Novi - Customer Relation Manager Garda Oto dalam Kunto, 2006:49).

Call center menjadi sangat penting ketika memperhatikan tingkat kesibukan masyarakat secara umum, di mana waktu menjadi sangat berharga bagi mereka. Oleh karena itu, Garda Oto sangat mengutamakan faktor "kemudahan akses konsumen ke perusahaan". Sebab, call center telah menjadi kebutuhan dalam menyelesaikan transaksi ataupun urusan-urusan pribadi secara cepat dan tuntas. Tahun 1998, tahun ketika kerusuhan sosial pecah di mana-mana, call center Garda Akses 24 jam tidak lagi menjadi cost center, melainkan mulai menjadi profit center.

PT Unilever Tbk. Jika jeli mengamati secara cermat, konsumen produk-produk Unilever tidak 
akan kesulitan mencari informasi yang dibutuhkan. Di setiap kemasan produk-produk Unilever tercantum nomor 08001558000 . Ini adalah nomor call center Unilever yang namanya "Suara Konsumen". Unilever memutuskan untuk mengelola sendiri call center-nya (in-house call center), dengan alasan mereka ingin memastikan bahwa pelayanan yang diberikan kepada pelanggan adalah maksimal, selain untuk kemudahan dalam "pengontrolan", sehingga bila ada komplain dari pelanggan dapat segera di tindaklanjuti.

Teknologi yang digunakan adalah ACD ( $A u$ tomatic Call Distribution). Sistem ini memastikan pembagian telepon itu merata untuk setiap officer. Jumlah agen yang menangani call center tergolong tidak banyak, hanya 6 agen untuk menangani ratarata call masuk setiap hari yang mencapai 100-150 buah. Para agen tersebut bukanlah karyawan Unilever melainkan outsource, tetapi proses rekrutmennya melibatkan Unilever.

PT Telkomsel. Merupakan perusahaan yang call center-nya bernama "CAROLINE TELKOMSEL", yang melayani tiga operasi, yaitu kartu Halo untuk korporate dengan n nomor call center nya 128 dan reguler 111 ; serta untuk produk AS dan Simpati: 116. Dari ketiga operasi tersebut, produk Simpati yang paling banyak mendapatkan tanggapan dari para pelanggannya. Telkomsel ini merupakan salah satu perusahaan yang paling banyak menggunakan officer (karyawan). Jumlahnya mencapai 1.000 orang lebih agen, mengingat jumlah pelanggan call center Caroline Telkomsel berjumlah 24 juta orang untuk berbagai layanan. Incoming call sehari mencapai 500.000 (Ririn Widayrani - GM Customer Service Telkomsel, dalam Jahari, 2006:54).

Awalnya, call center Telkomsel tersebut mengikuti lokasi kota-kota di mana Telkomsel hadir, dengan menawarkan hanya layanan informasi dan keluhan. Pada tahun 2000, barulah dilakukan pengerucutan dengan menggabungkan jumlahnya yang banyak menjadi hanya empat, yaitu kota Medan, Jakarta, Surabaya, dan Bandung dengan membangun sistem secara lengkap dan menambah fitur-fitur layanan terbaru (antara lain layanan pembayaran kartu Halo dan permintaan aktivasi), serta aksesnya dibuka selama 24 jam per hari. Pada tahun 2006, Telkomsel merencanakan untuk menambah kapasitas. Inovasi yang dilakukan pada perubahan kali ini tidak hanya melayani inbound call, tetapi juga outbound call. Seluruhnya akan di-outsource-kan ke pihak lain (baik officer, manajemen, maupun infrastrukturnya). Selama ini, outsource hanya dilakukan pada karyawan, sedangkan manajemen dan infrastrukturnya ditangani sendiri. Call center di mata PT. Telkomsel sangat penting artinya, karena menyangkut pelayanan kepada pelanggan. Yang membedakan call center Caroline Telkomsel dengan pesaingpesaingnya yaitu pada pelaksanaannya call center yang day to day.

Guna menanggulangi turn over para officer (karyawan), PT.Telkomsel memberikan encourage dan melakukan refreshing dan memberikan penghargaan kepada operator terbaik. Mereka diberi 15 kali gaji termasuk THR dan cuti akhir tahun.

Hotline AIDS. Call center tidak digunakan oleh perusahaan profit motif saja, tetapi ia juga dapat digunakan oleh lembaga nonprofit motif yang mengusung misi sosial seperti yang dilakukan oleh Hotline AIDS, sebuah lembaga yang khusus melayani masalah AIDS, narkoba, dan masalahmasalah sosial lainnya. Sejarah Hotline AIDS ini tidak terlepas dari POKDISUS (Kelompok Studi Khusus) AIDS yang didirikan pada tahun 1980an. Lembaga ini dibentuk karena ada kebutuhan masyarakat akan informasi tentang AIDS yang terus meningkat, sedangkan layanan informasi di rumah sakit di Indonesia masih sangat terbatas. Dari masalah tersebut, tercetus ide dari kelompok tersebut untuk membuat hotline AIDS. Pada tahun 1993, ide tersebut berhasil diwujudkan berkat kerjasama POKDISUS dengan radio Prambors, Telkom dan Multipolar (Kurniawan Rahmadi, Project Manager POKDISUS AIDS, dalam Simatupang, Akbar, 2006:57).

Adapun layanan yang diberikan Hotline AIDS tersebut, antara lain: layanan konseling, informasi AIDS, informasi tentang dokter terapi AIDS, serta obat yang digunakan untuk mengobati AIDS. 
Hotline AIDS dibuka setiap hari dan terdiri dari 7 line sehingga dapat menerima 7 penelepon secara bersamaan. Agennya tidak banyak, cuma tujuh orang konselor. Para konselor tersebut adalah anggota lembaga POKDISUS yang memiliki pengetahuan dan kemampuan sebagai seorang konseler. Mereka telah melalui pelatihan demi pelatihan tentang konseling, obat-obatan, dan penatalaksanaan HIV/AIDS. Para konseler ini sangat menjaga kerahasiaan pelanggannya.

\subsection{Perusahaan Provider Call Center}

Perusahaan Infomedia Nusantara merupakan salah satu provider call center yang paling berpengaruh di industri ini. Kekuatannya ada pada teknologi, SDM, dan proses. Sejumlah perusahaan besar telah menjadi kliennya, seperti Sonny Ericson untuk layanan customer service, Bank ABN Amro dan Bank Niaga untuk layanan phone banking. Kini call center mereka telah melayani sekitar 32 perusahaan dengan 58 macam layanan.

Nomor akses layanan call center yang dikelola Infomedia cukup beragam sesuai dengan pilihan yang diinginkan oleh kliennya. Ada nomor biasa, lima digit (140XX), tol free $(0800-\mathrm{XXX}-\mathrm{XXX})$, dan unicall (0807-XXX - XXX). Jenis layanan yang diberikan terdiri dari layanan inbound dan outbound. Sedangkan fasilitas yang disediakan terdiri dari gedung, perangkat hardware, software, jaringan komunikasi data \& voice, serta SDM. SDM di mata Infomedia merupakan alat utama call center. Sebab, membangun call center berarti juga membangun SDM, yang memiliki kemampuan berkomunikasi yang baik, menguasai produk, mengatasi permasalahan pelanggan, serta harus menguasai tata bahasa yang baik.

Selain ungggul dalam SDM yang dimiliki, Infomedia juga memiliki teknologi call center yang canggih, di mana ia memiliki teknologi call center Digital \& PBX, CMS, IVR, CTI, CDR, Voice Recording, serta $D B$ Server \& Application.

Untuk ke depan, teknologi call center akan berbeser dari Digital ke IP Base, dan istilah call center akan berbeser menjadi multimedia contact center. Perusahaan Infomedia sudah mengantisipasi perubahan tersebut dengan meng upgrade perangkat-perangkat digital menjadi IP Base di beberapa lokasi, dan call center Infomedia telah berubah menjadi Contact Center Infomedia.

\subsection{Tren Contact Center di Asia Pasifik}

Asia Pasifik merupakan kawasan yang dinamis. Sebagai sebuah blok perdagangan, kawasan ini cukup diperhitungkan. Geliat pasarnya pun dari tahun ke tahun terus meningkat. Negara-negara, seperti Jepang, Cina, Korea, Singapura, diyakini merupakan pendorong tumbuhnya pasar di Asia Pasifik. Perkembangannya tidak hanya dari sisi output yang dihasilkan, namun juga infrastruktur pemasarannya yang semakin canggih dengan dukungan teknologi informasi yang memadai.

Call center yang sering juga dinamakan contact center atau customer interaction center, pada intinya, adalah pusat pelayanan pelanggan. Awalnya, disebut call center karena kontak dengan pelanggan $100 \%$ melalui telepon. Namun dewasa ini, dengan teknologi infrastruktur telepon yang terus berkembang, dengan menerapkan Intelegent network - yang salah satu penerapannya adalah nomor bebas pulsa 1-800 - sampai kepada pengembangan voice network oleh CISCO IPCC (Internet Protocol Contact Center), di mana komunikasi suara sudah memanfaatkan teknologi internet.

Satu hal yang menarik dalam perkembangan industri contact center di kawasan Asia Pasifik adalah adanya upaya menggeser contack center menjadi bagian dari strategi bisnis dengan cara melihat contact center sebagai profit center, bukan lagi sebagai cost center. Hal tersebut dapat dilakukan bila setiap kali telepon ada pembayaran (Ghozali, 2006: 38).

Selanjutnya, Ghozali mengatakan bahwa menurut data yang dirilis Frost \& Sullivankonsultan dan biro riset pemasaran pada tahun 2004, industri contact center di Asia Pasific mengalami peningkatan yang cukup bagus. Hal ini tampak bukan saja dari jumlah contact center, tetapi juga dari jumlah agennya. Selain karena faktor meningkatnya penanganan layanan pelanggan yang lebih baik, pertumbuhan tersebut juga didorong oleh fenomena global outsourcing 
contact center.

Dalam pengelolaan contact center, banyak perusahaan di Asia Pasifik lebih memilih melakukan sewa ke pihak ketiga. Hal ini tampak dari meningkatnya permintaan outsourcing di negaranegara Jepang, Australia, serta Korea Selatan. Outsourcing merupakan pilihan strategis untuk lebih efektif dan efisien sehingga perusahaan bisa lebih fokus pada core business-nya.

Pada tahun 2004, beberapa kelompok industri - seperti perbankan, jasa keuangan, asuransi, yang diikuti oleh perusahaan Telekomunikasi dari IT merupakan kontributor utama dalam jumlah contact center seats di Asia Pasifik. Kebutuhan akan fasilitas contact center untuk layanan pelanggan di industri ini meningkat secara signifikan, di mana peranannya terhadap total seats di Asia Pasifik mencapai hampir 50\%. Lembaga pemerintahan, lembaga pendidikan, serta lembaga ritel merupakan kelompok lain yang tengah mengalami tren untuk memanfaatkan contact center dalam rangka memperbaiki customer service.

Era persaingan yang ketat telah mendorong banyak perusahaan untuk terus menerus mempertahankan pelanggannya. Hal inilah yang mendorong industri contact center di kawasan Asia Pasifik terus tumbuh dan memiliki tren cukup bagus. Pertumbuhan ini juga didorong oleh berkembangnya jasa outsourcing di kawasan Asia Pasifik, seperti: di India dan Filipina. Saat ini, semakin banyak perusahaan yang melakukan outsourcing sampai lintas negara (offshoring). Contoh: beberapa perusahaan Jepang dan Korea melakukan offshoring ke Cina. Jadi, contact centernya menyewa dari perusahaan Cina. Perusahaan Singapura melakukan offshoring, di mana contact center nya berada di Malaysia. Perusahaan Australia contact center-nya berada di India dan Filipina.

\subsection{Analisis Call Center sebagai Alat Komunikasi Pemasaran Abad 21}

Telah dikemukakan bahwa di abad ke-21 ini dengan semakin berkembangnya dunia informasi telah menyebabkan kebutuhan dan keinginan konsumen menjadi semakin kompleks, semakin banyak tuntutan konsumen terhadap penawaran perusahaan. Kondisi seperti ini mau tidak mau harus disikapi dengan bijaksana oleh para produsen. Perusahaan yang peduli akan kepuasan pelanggan akan terus menerus memfasilitasi kemudahan akses pelanggan ke perusahaan. Dengan berkembangnya soft ware database pelanggan, sekarang call center dapat digunakan secara aktifoleh perusahaan untuk menghubungi pelanggan.

Membangun call center yang baik membutuhkan tidak saja investasi yang besar, baik untuk infrastruktur, maupun untuk SDM yang berkualitas. Namun manfaat yang diperoleh dari call center tersebut, perusahaan akan mampu berkomunikasi secara langsung dengan pelanggan, sehingga akan meningkatkan kepuasan pelanggan, yang pada akhirnya akan terjalin hubungan jangka panjang dengan pelanggannya,

Untuk membangun call center di Indonesia, di mana mayoritas perusahaannya adalah perusahan Usaha Menengah Kecil dan Mikro (UMKM) merupakan hal yang masih sulit dilakukan. Ada beberapa alasan mengapa UMKM belum memiliki call center, antara lain mereka belum terbiasa dengan information technology (IT), mereka belum menganggap penting keberadaan call center, mereka merasa terlalu berat untuk membangun call center, mereka belum menyadari bahwa betapa pentingnya sebuah call center sebagai media perusahaan berkomunikasi langsung dengan pelanggannya, sehingga akan terjalin hubungan jangka panjang dengan pelanggannya, serta akan meningkatkan kepuasan mereka terhadap kinerja perusahaan.

Guna mengatasi hal tersebut, diperlukan upaya-upaya yang dilakukan oleh pemerintah dan lembaga-lembaga nonpemerintah, selain memberikan bantuan pendirian call center, juga memberikan pengetahuan tentang pentingnya call center sebagai media meningkatkan kepuasan pelanggan mereka, meyakinkan mereka bahwa lebih banyak manfaat yang akan mereka peroleh dengan memiliki call center daripada biaya yang harus mereka keluarkan. 


\section{Kesimpulan}

Call center pada intinya merupakan pusat layanan pelanggan, yang pada awalnya kontak pelanggan $100 \%$ menggunakan telepon, kemudian dengan berkembangnya teknologi, munculah intelegent network yang salah satu aplikasinya menggunakan nomor bebas pulsa. Call center yang merupakan bagian dari contact center pada dasarnya, merupakan alat pemasaran langsung, yang diyakini mampu membangun hubungan jangka panjang dengan pelanggan.

Tujuan call center pertama-tama adalah untuk memberikan suatu media buat para konsumen atau pasar sasaran berbicara dengan perusahaan. Sehingga perusahaan akan mampu menampung apa keinginan dan harapan para konsumen terhadap produk-produk perusahaan. Dengan mengetahui harapan dan keinginan para konsumen, maka perusahaan merupakan peluang untuk melakukan inovasi, peningkatan mutu produk. Dengan kata lain, keberadaan call center diyakini oleh para produsen akan mampu meningkatkan kepuasan pelanggan, dengan alasan: (1) Biaya kontak seorang pelanggan ke perusahaan lebih murah dibandingkan dengan menyediakan waktu khusus bagi pelanggan untuk datang ke perusahaan. Begitu juga, bagi perusahaan, makin banyak tempat layanan disediakan, maka biaya investasi dan biaya operasional menjadi semakin mahal. Dengan call center, biaya pelayanan per pelanggan dapat ditekan dalam jangka menengah dan jangka panjang; (2) Karena akses pelanggan ke perusahaan lebih cepat dan lebih murah, maka pelanggan yang dilayani dengan tuntas akan jauh lebih puas, karena telah mendapatkan value yang diinginkan. Jadi, manfaat yang diperoleh dari memiliki call center lebih besar daripada biaya yang dikeluarkan; (3) Pelanggan yakin akan profesionalisme perusahaan yang memiliki call center, sehingga dapat mening-katkan citra positif perusahaan dibenak pelanggan.

\section{Daftar Pustaka}

Agung, Yuliana. 2006. "Pendekatan yang paling Cespleng adalah lewat Experiential Marketing." Majalah Marketing, No. 06/ V/ Februari/ 2006, hlm. 28.

Ghozali, Anang. 2005. "Tren Contact Center Di Asia Pasifik." Majalah Marketing, No. 06/ V/ Februari/2006, hlm. 31.

Indrajit, Richard Eko. 2006. "Harus Bisa Beyond Expectation." Majalah Marketing, No.02/ VI/ Februari/2006, hlm. 30.

Jahari, Tajwini. 2006. "Investasi Miliaran Tanpa Hasil?" Majalah Marketing, No.02/ VI/ Februari/2006, hlm. 23, 24, 25, 54.

Kerin,Roger A., Peterson, Robert A. 1993. Strategic Marketing Problems, Cases and Comments. Sixth Edition, Massachusetts: Ally and Bacon A Division of Simon \& Schuster, Inc.

Kotler,Philip,Gary Amstrong. 2001. Principles Of Marketing. Ninth Edition.New Jersey: Prentice Hall, Inc.

Kotler,Philip. 2003. Marketing Management: Analysis, Planning, Implementation and Control. Millenium Edition. USA: Prentice Hall Inc.

Kunto,AA. 2006. "Kemudahan Akses Diutamakan." Majalah Marketing, No.003/ VI/ Juni/2006, hlm. 49.

Simatupang, David, Miranda Hutagalung. 2006. "Layanan Juga Harus Cantik." Majalah Marketing, No.002/ VI/ Juni/2006, hlm. 40, 41, 44.

Simatupan, Davi, Rofian Akbar. 2006. Kerahasiaan Identitas Sangat Dijaga. Majalah Marketing, No.002/ VI/ Juni/2006, hlm. 57. 
